\title{
Protective Effect and Mechanism of $\alpha$-Lipoic Acid on Partial Hepatic Ischemia-Reperfusion Injury in Adult Male Rats
}

\author{
Yun REN ${ }^{1}$, Li-Hua WANG ${ }^{1}$, Fu-Sheng DENG ${ }^{1}$, Jian-Sheng LI ${ }^{1}$, Lin JIANG ${ }^{1}$ \\ ${ }^{1}$ The First Affiliated Hospital of USTC, Division of Life Sciences and Medicine, University of \\ Science and Technology of China, Hefei, China
}

Received November 23, 2018

Accepted June 6, 2019

Epub Ahead of Print August 19, 2019

\section{Summary}

In order to reduce tissue damage caused by ischemia-reperfusion injury, this study aims to investigate the protective effect and mechanism of a-lipoic acid on hepatic ischemia-reperfusion injury in rats. The bloodstream of rats was blocked in the left middle and left lateral liver lobes of the liver. Forty rats were randomly divided into two groups: treatment group and injury group. Rats were injected with either $25 \mathrm{mg} / 1 \mathrm{ml}$ of a-lipoic acid (treatment group) or $1 \mathrm{ml}$ of saline (injury group) into the caudal vein $15 \mathrm{~min}$ before hepatic ischemia-reperfusion. Rat serum alanine aminotransferase (GPT), glutathione (GSH) and superoxide dismutase (SOD) levels were examined at various time points $(1,3,6$ and $12 \mathrm{~h})$ in both groups. Changes in nuclear factor kappa B P65 (NF-KB P65) expression in ischemia-reperfusion liver at various time points after reperfusion $(1,3,6$ and $12 \mathrm{~h}$ ) were evaluated through immunohistochemistry assay. Changes in macrophage inflammatory protein-2 (MIP-2) mRNA and inducible nitric oxide synthase (iNOS) mRNA expression in ischemic reperfused rat livers were detected by RT-PCR. Serum GPT level was significantly higher in the injury group than in the treatment group $(P<0.01)$. NF-kB P65, MIP-2 mRNA and iNOS mRNA expression in ischemic reperfused rat livers were significantly higher in the injury group than in the treatment group $(P<0.01)$. Serum GSH and SOD levels were higher in the treatment group than in the injury group $(P<0.01)$. Alpha-lipoic acid significantly reduced ischemia-reperfusion injury in rat livers. This may be associated to the direct scavenging of oxygen-free radicals, increased GSH production, and the activation of downstream media due to decreased NF-KB and GSH consumption.

\section{Key words}

Ischemia • Reperfusion injury • a-Lipoic acid • Liver • Oxygen free radicals

\section{Corresponding author}

Y. Ren, The First Affiliated Hospital of USTC, Division of Life Sciences and Medicine, University of Science and Technology of China, Hefei, China. E-mail: renyun880923@163.com

\section{Introduction}

Ischemia-reperfusion injury is a common pathological process in liver diseases and trauma. Ischemia reperfusion injury refers to damage to the tissue or organ after ischemia followed by blood supply discontinuation, but when the blood supply to the ischemic tissue and organ function recover, the metabolic disorder and structure damage even aggravate. Hepatic ischemia-reperfusion injury is one of the important causes of liver dysfunction, primary liver transplantation, hepatic insufficiency and liver failure after liver surgery. Ischemia-reperfusion injury is a common pathological process in liver diseases and trauma. It is also the main reason for poor liver function after liver surgery (Ocuin et al. 2012). It has been reported that hepatic ischemiareperfusion (HIR) injury undergoes two steps (Kim et al. 2015). Early reperfusion: The generation of reactive oxygen during the reflow process directly damages the liver cell membrane, leading to cell damage and the release of cellular contents. This further increases the production of oxygen-free radicals, which harm endothelial cells and cause the loss of microcirculation 
integrity and the reduction of the bloodstream. Neutrophils are aggregated and activated in the early stage of liver microcirculation, which aggravates reperfusion injury. Late reperfusion: The injury is mediated by microcirculation disturbance and neutrophils. Alpha-lipoic acid (LA) is a kind of vitamin, and is a coenzyme of the oxidative decarboxylation of alpha-keto acid in the tricarboxylic acid cycle. LA is a water-soluble and fat-soluble metabolic antioxidant. It is one of the most powerful and active antioxidants. This study attempted to explore the effect and mechanism of LA on HIR based on the model of HIR injury in rats. LA is a broad antioxidant that plays an extensive role in cell protection, radical scavenging and antioxidation (Peralta et al. 2013). LA and dihydrolipoic acid reciprocally convert and form a dynamic equilibrium in animals. LA is 5 to 10 times as potent as grape seeds, and the antioxidant power of grape seeds is 20 times that of vitamin $C$, and 60 times of that of vitamin E. It has both fat soluble and water-soluble characteristics, can be absorbed by various tissues of organs. They directly remove a large amount of oxygen-free radicals, except for superoxide-free radicals and hydrogen peroxide (Zhang et al. 2011), and increase the ATP levels of tissues.

\section{Methods}

\section{Experimental animals and groups}

A total of 40 male Wistar rats $(220-280 \mathrm{~g}$, purchased from the Experimental Animal Center, Anhui Medical University) were randomly divided into two groups: treatment group and injury control group; with 20 rats in each group. All experimental animals were anesthetized with $2 \%$ nembutal (pentobarbital) $(40 \sim 50 \mathrm{mg} / \mathrm{kg})$ intraperitoneal injection, underwent 12-hour preoperative fasting, and were provided drinking water ad libitum. Then, rats were fixed in the supine position, and an incision was performed on the ventral midline. The portal vein leading to the left and right hepatic lobe, as well as to the hepatic artery and bile duct, were isolated in the hepatic portal. The bloodstream was blocked in the left middle and left hepatic lateral lobe of the liver, but not in the right lobe, in order to prevent portal vein and intestinal tract congestion (Nunes et al. 2011). Rats in the treatment group and injury group were injected with $1 \mathrm{ml}$ of LA $(25 \mathrm{mg} / 1 \mathrm{ml}$, purchased from Anhui Medical University) and with $1 \mathrm{ml}$ of normal saline (NS), respectively, at $15 \mathrm{~min}$ before reperfusion and $60 \mathrm{~min}$ after ischemia. Two $\mathrm{ml}$ of arterial blood and liver tissue samples were extracted after reperfusion $(1,3$, 6 and 12 h) in each group.

This study was conducted in accordance with the Declaration of Helsinki. This study was conducted with approval from the Ethics Committee of Anhui Provincial Hospital Affiliated to Anhui Medical University.

\section{Determination of GPT, GSH and SOD in serum}

SOD and GPT were determined according to kit instructions. GSH in serum was measured using the Reitman Frankel method. All reagent kits were purchased from Nanjing Jiancheng Bioengineering institute.

Immunohistochemical analysis of hepatic NF- $\kappa B$ P65 expression

Liver specimens were fixed with formaldehyde. The protein was detected with the antibody of NF-кB P65 (1:150, Newsmarker Co.). The known myocardial biopsy was used as the positive control, and phosphate-buffered saline (PBS) was used as the negative control instead of a primary antibody. The brown granules were present in the endochylema of positive cells. The JEDA810D software was used to analyze the positive staining integral optical density (IOD), and the obtained value was used as the IOD of the sample.

Expression analysis of MIP-2mRNA and iNOS $m R N A$ in liver tissue

Liver samples were collected and stored immediately with liquid nitrogen. One-hundred $\mathrm{mg}$ of tissues were grounded in $1 \mathrm{ml}$ of Trizol buffer, and total RNA was extracted using a Promega kit. RNA concentration was confirmed through the $A$ value. The RNA was reverse-transcribed by OligodT primer in a $25-\mu 1$ reaction system with the "two step" method. PCR primers were synthesized by Shanghai Sangon Biotech, and the relative sequences and sizes of the PCR products were as follows:

MIP-2:

F: 5'-TGCTGTACTGGTCCT-GCTC-3', R: 5'-TTTGATTCTGCCCGTTGA-3', 323 bp;

INOS:

F: 5'-TCGAGCCCTGGAAGACCCACAT-ATG-3', R: 5'-CTGGAAGGTGGACAGTGAG-3', 250 bp;

$\beta$-actin:

F: 5'-GAGGGAAATCGTGCGTGAC-3', R: 5'-CTGGAAGGTGGACAGTGAG-3', 536 bp.

The PCR products were analyzed by $2 \%$ agarose gel electrophoresis. The values of MIP-2 and 
iNOS were quantified with the ratios between MIP-2 or iNOS and $\beta$-actin using a gel image analysis system.

\section{Statistics analysis}

Data were analyzed using SPSS 11.0 software and expressed as mean \pm standard deviation $(\mathrm{x} \pm \mathrm{SD})$. The test of significance was performed using the $F$-test.

\section{Results}

Effect of LA on hepatic enzymes in serum after ischemiareperfusion

After reflow, GPT levels gradually increased, and peaked after six hours of reflow. Then, this level was slowly reduced. The GPT value in the treatment group was lower than that in the injury group at each time period after reflow $(P<0.01$, Table 1$)$. The difference was statistically significant.

Effect of LA on liver enzyme indexes after ischemiareperfusion injury

After reflow, GSH levels gradually decreased, reached the lowest point within 3-6 h, and slowly increased after six hours of reflow. GSH in serum in the treatment group was higher than that in the injury group at each time period $(P<0.01$, Table 1$)$, which suggests that LA could increase the content of GSH and reduce its consumption. GSH content continuously decreased within 1-6 h after reflow, and began to rise at six hours. After reflow, SOD levels gradually decreased, reached the lowest point within 3-6 h, and slowly increased after six hours of reflow. Furthermore, SOD level in the treatment group was higher than that in the injury group at each time period $(P<0.01$, Table 1$)$.

Table 1. The levels of GPT, GSH and SOD in rat serum of different groups.

\begin{tabular}{|c|c|c|c|c|c|c|c|c|c|c|c|c|c|}
\hline \multirow{2}{*}{ Group } & \multirow{2}{*}{ Case } & \multicolumn{4}{|c|}{ GPT (U/l) } & \multicolumn{4}{|c|}{ GSH (mg/ml) } & \multicolumn{4}{|c|}{ SOD (U/ml) } \\
\hline & & $1 \mathrm{~h}$ & $3 \mathrm{~h}$ & $6 \mathrm{~h}$ & $12 \mathrm{~h}$ & $1 \mathrm{~h}$ & $3 \mathrm{~h}$ & $6 \mathrm{~h}$ & $12 \mathrm{~h}$ & $1 \mathrm{~h}$ & $3 \mathrm{~h}$ & $6 \mathrm{~h}$ & $12 \mathrm{~h}$ \\
\hline \multirow{2}{*}{$A$} & \multirow{2}{*}{5} & 208.7 & 247.3 & 290.4 & 237.9 & 0.213 & 0.176 & 0.197 & 0.213 & 146.14 & 107.43 & 85.61 & 106.64 \\
\hline & & \pm 20.25 & \pm 20.74 & \pm 21.05 & \pm 18.12 & \pm 0.004 & \pm 0.008 & \pm 0.010 & \pm 0.008 & \pm 4.30 & \pm 5.52 & \pm 4.81 & \pm 5.09 \\
\hline \multirow{2}{*}{$B$} & \multirow{2}{*}{5} & 124.1 & 113.1 & 147.4 & 185.8 & 0.284 & 0.279 & 0.231 & 0.253 & 158.32 & 126.30 & 105.58 & 125.29 \\
\hline & & $\pm 6.348^{\#}$ & $\pm 8.457^{\#}$ & $\pm 12.23^{\#}$ & $\pm 14.56^{\#}$ & $\pm 0.004^{\#}$ & $\pm 0.007^{\#}$ & $\pm 0.030^{\#}$ & $\pm 0.029^{\#}$ & $\pm 13.50^{\#}$ & $\pm 15.49^{\#}$ & $\pm 14.97^{\#}$ & $\pm 12.90^{\#}$ \\
\hline
\end{tabular}

Note: $*$ and ${ }^{\#}$ separately indicate significance at $P=0.05$ and $P=0.01$ in B group compared with A group. A group is control group; $B$ group is treatment group.

Effect of LA on the protein expression of $N F-\kappa B P 65$ in the liver after ischemia-reperfusion injury

$\mathrm{NF}-\kappa \mathrm{B}$ is an ubiquitous nuclear transcription factor, which is involved in the transcriptional regulation of various genes, inflammatory reactions, immune responses, as well as cell hyperplasia transformation and apoptosis (Yamada et al. 2012). In most cell types, $\mathrm{NF}-\kappa \mathrm{B}$ binds to cytoplasmic and inhibitory proteins to form inactive complexes. When applied to corresponding tumor necrosis factor receptor, it can be activated by the second messenger Cer, and virus infection, activation of lipopolysaccharide, reactive oxygen intermediates, phorbol ester, double stranded RNA and the signaling pathways in RKC and PkA can directly activate NF- $\mathrm{BB}$. Activation process results in the activation of NF- $\kappa$ B by phosphorylation of the inhibitory protein, resulting in its conformational change from $N F-\kappa B$. The activated $\mathrm{NF}-\kappa \mathrm{B}$ translocates into the nucleus, binds to DNA, and start the transcription inhibition of related genes. After reflow, NF-кB P65 level gradually increased, peaked at six hours after reflow, and slowly declined. Immunohistochemical analysis of the NF P65 B subunit demonstrated that these two groups all contained claybank granules in the cell endochylema, and the expression of NF- $\mathrm{BB}$ P65 in the injury group was higher than that in the treatment group $(P<0.01$, Table 2$)$. After three hours of reperfusion, NF- $\mathrm{B}$ P65 significantly increased (Fig. 1), peaked after six hours (Fig. 2), and then began to decline (Fig. 3).

Effect of LA on MIP-2mRNA and iNOS mRNA in liver tissue after ischemia-reperfusion injury

MIP-2 is a potent neutrophil chemokine, which is a member of the chemokines C-X-C families (Xue et al. 2011, Tao et al. 2014). MIP-2 is an important chemokine, has a dual role in the body: on the one hand, the specificity of chemotaxis of neutrophils to tissue inflammation, strengthen the clearance of neutrophils to pathogens, 
defense response in the body; on the other hand, MIP-2 can activate neutrophils to release excess myeloperoxidase enzyme, cause tissue injury. After reflow, MIP-2 mRNA expression gradually increased, and was maintained at a high level at $12 \mathrm{~h}$ of reflow. MIP-2 mRNA levels in the treatment group was lower than that in the injury group at each time period $(P<0.01$; Table 2 , Fig. 4$)$. Nitric oxide (NO) is not only the vasorelaxation factor of endothelial cells, but also a kind of free radical. L-arginine is catalyzed by NO synthase (NOS), which forms NO in the human body. NOS is divided into three categories: endothelial nitric oxide synthetase (eNOS), iNOS, and neuronal nitric oxide synthetase (nNOS) (Gehrau et al. 2015). After reflow, iNOS mRNA level gradually increased, peaked after six hours of reflow, and slowly declined. Furthermore, iNOS mRNA expression levels in the treatment group was lower than that in the injury group at each time point $(P<0.01$; Table 2, Fig. 5).

Table 2. The expression levels of NF-KB P65, MIP-2 mRNA and iNOS mRNA in rats of different groups.

\begin{tabular}{|c|c|c|c|c|c|c|c|c|c|c|c|c|c|}
\hline \multirow{2}{*}{ Group } & \multirow{2}{*}{ Case } & \multicolumn{4}{|c|}{ NF-кB P65 } & \multicolumn{4}{|c|}{ MIP-2 mRNA/ $\beta$-actin mRNA } & \multicolumn{4}{|c|}{ iNOS mRNA/ $\beta$-actin mRNA } \\
\hline & & $1 \mathrm{~h}$ & $3 \mathbf{h}$ & $6 \mathrm{~h}$ & $12 \mathrm{~h}$ & $1 \mathrm{~h}$ & $3 \mathbf{h}$ & $6 \mathrm{~h}$ & $12 \mathrm{~h}$ & $1 \mathrm{~h}$ & $3 \mathbf{h}$ & $6 \mathrm{~h}$ & $12 \mathrm{~h}$ \\
\hline$A$ & 5 & $\begin{array}{c}0.270 \pm \\
0.031\end{array}$ & $\begin{array}{c}0.377 \pm \\
0.067\end{array}$ & $\begin{array}{c}0.372 \pm \\
0.055\end{array}$ & $\begin{array}{c}0.332 \pm \\
0.018\end{array}$ & $\begin{array}{c}0.756 \pm \\
0.016\end{array}$ & $\begin{array}{c}0.842 \pm \\
0.009\end{array}$ & $\begin{array}{c}0.914 \pm \\
0.012\end{array}$ & $\begin{array}{c}0.958 \pm \\
0.010\end{array}$ & $\begin{array}{c}0.562 \\
\pm 0.013\end{array}$ & $\begin{array}{c}0.710 \\
\pm 0.015\end{array}$ & $\begin{array}{c}0.946 \\
\pm 0.011\end{array}$ & $\begin{array}{c}0.756 \\
\pm 0.070\end{array}$ \\
\hline$B$ & 5 & $\begin{array}{l}0.187 \pm \\
0.021^{\#}\end{array}$ & $\begin{array}{l}0.285 \pm \\
0.023^{\#}\end{array}$ & $\begin{array}{l}0.264 \pm \\
0.028^{\#}\end{array}$ & $\begin{array}{l}0.260 \pm \\
0.022^{\#}\end{array}$ & $\begin{array}{l}0.542 \pm \\
0.009^{\#}\end{array}$ & $\begin{array}{l}0.655 \pm \\
0.013^{\#}\end{array}$ & $\begin{array}{l}0.683 \pm \\
0.018^{\#}\end{array}$ & $\begin{array}{l}0.724 \pm \\
0.009^{\#}\end{array}$ & $\begin{array}{c}0.487 \\
\pm 0.012^{\#}\end{array}$ & $\begin{array}{c}0.625 \\
\pm 0.008^{\#}\end{array}$ & $\begin{array}{c}0.777 \\
\pm 0.013^{\#}\end{array}$ & $\begin{array}{c}0.646 \\
\pm 0.015^{\#}\end{array}$ \\
\hline
\end{tabular}

A

A
$\because$
$\therefore$
C

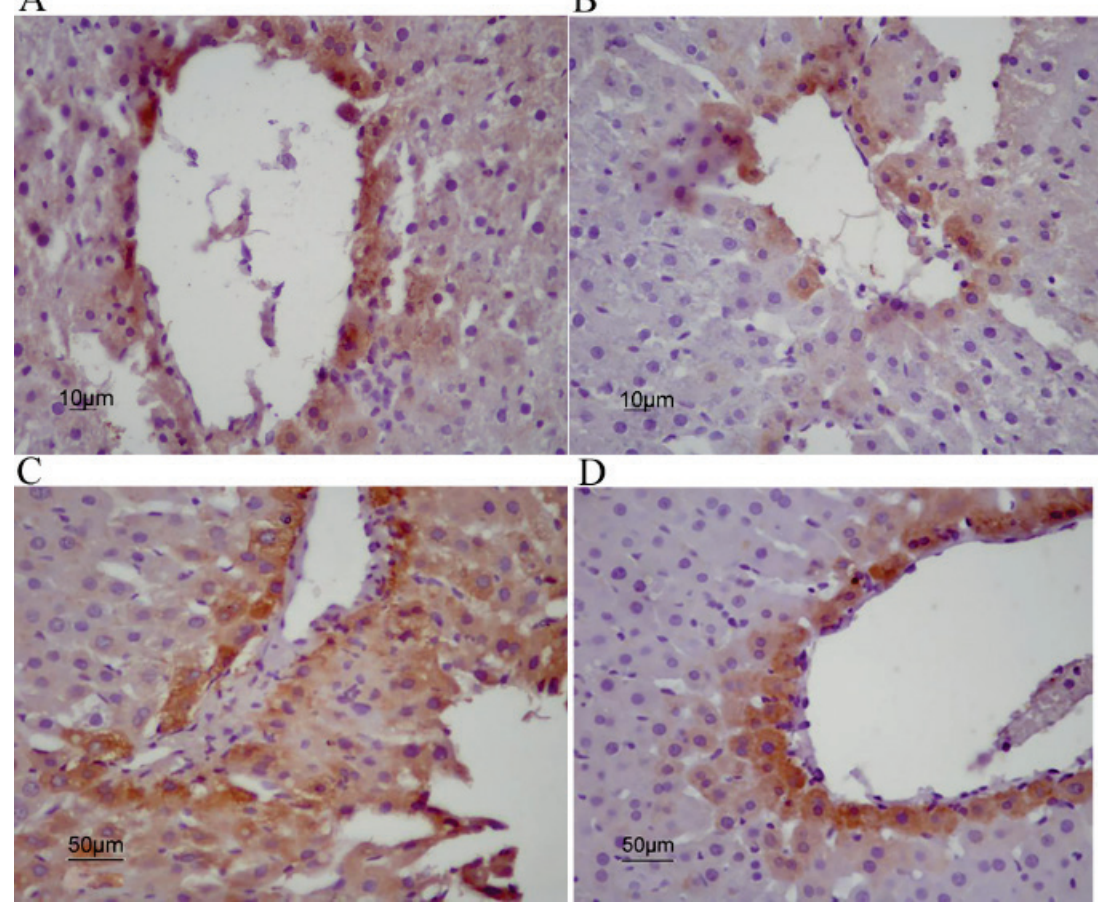

B

A

B

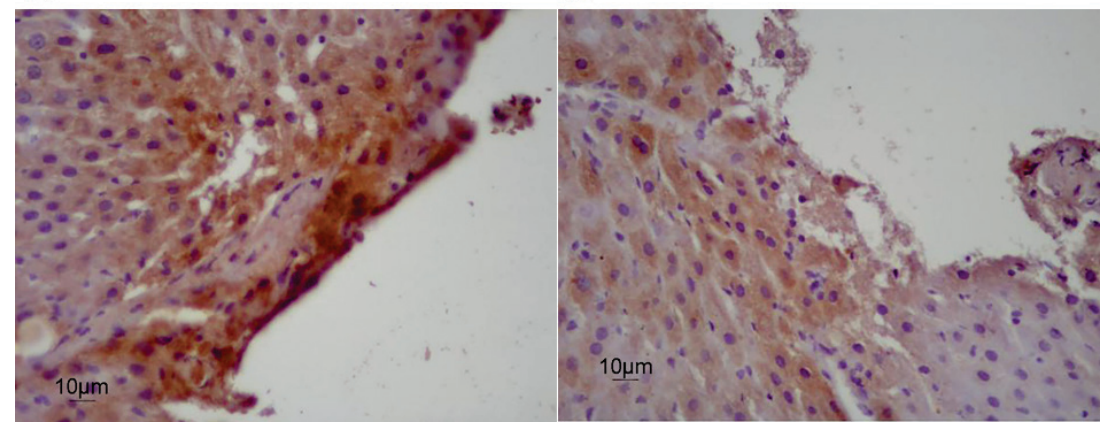

Fig. 1. (A) Expression of NF-kBp65 in the liver of injury group $(n=5) 1 \mathrm{~h}$ after reperfusion. Immunohistochemical staining $\times 400$; (B) Expression of NF-KBp65 in the liver of treatment group $(n=5) 1 \mathrm{~h}$ after reperfusion. Immunohistochemical staining $\times 400 ; \quad$ (C) Expression of NF-KBp65 in the liver of injury group $(\mathrm{n}=5) 3 \mathrm{~h}$ after reperfusion. Immunohistochemical staining $\times 400$; (D) Expression of NF-KBp65 in the liver of treatment group $(n=5) \quad 3 \mathrm{~h}$ after reperfusion. Immunohistochemical staining $\times 400$.

Fig. 2. (A) Expression of NF-KBp65 in the liver of injury group $(n=5) 6 \mathrm{~h}$ after reperfusion. Immunohistochemical staining $\times 400 ; \quad$ (B) Expression of NF-KBp65 in the liver of treatment group $(n=5) 6 \mathrm{~h}$ after reperfusion. Immunohistochemical staining $\times 400$. 


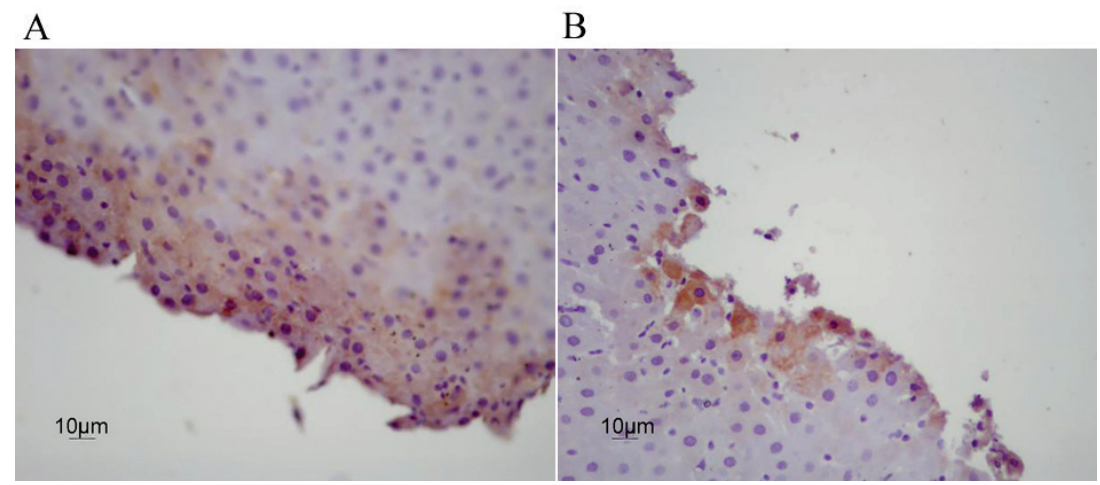

Fig. 3. (A) Expression of NF-KBp65 in the liver of injury group $(n=5) 12 \mathrm{~h}$ after reperfusion. Immunohistochemical staining $\times 400 ; \quad$ (B) Expression of NF-KBp65 in the liver of treatment group $(n=5) 12 \mathrm{~h}$ after reperfusion. Immunohistochemical staining $\times 400$.

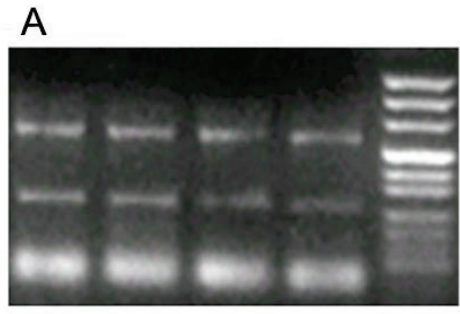

$12 \mathrm{~h} \quad 6 \mathrm{~h} \quad 3 \mathrm{~h} \quad 1 \mathrm{~h}$

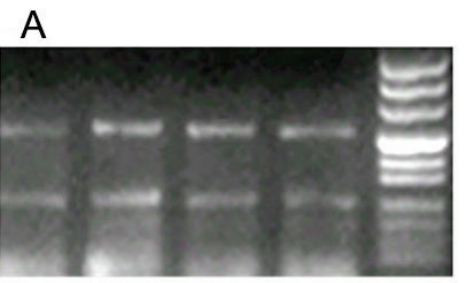

$12 \mathrm{~h} \quad 6 \mathrm{~h} \quad 3 \mathrm{~h} \quad 1 \mathrm{~h}$

\section{Discussion}

The critical factor for the injury of hepatocytes is the external invasion of neutrophils. The disturbance of microcirculation and the phenomenon of "no reflow" in the hepatic sinus are important reasons of ischemiareperfusion injury. This shows a high expression of some inflammatory factors including intercellular adhesion molecule-I (ICAM-1), MIP-2 and iNOS (Mignini et al. 2013, Abdel-Gaber et al. 2015, Tanaka et al. 2015). A previous study revealed that protein expression patterns were regulated to adapt to oxidative stress by activating redox-sensitive transcription factors [such as erythrocyte glutathione reductase-1 (Egr-1), NF- $\mathrm{kB}$, transcription factor AP-1 and G protein] and cellular kinases [such as mitogen-activated protein kinase (MAPK) family] in mammalian cells (Abdin et al. 2011). Then, a chain reaction of inflammation is activated and further causes injury to tissues and organs by the activation of transcription factors such as NF-kB and AP-1 (Gehrau et al. 2015).

In this study, we observed the GPT content in the injury and treatment groups, and found that LA had a significant protective effect on liver function in all time points. This might be related to the reduction in LA oxidative stress and the braking of a single DNA strand (Ghibu et al. 2008). GSH has been confirmed to directly participate in the scavenging of oxygen-free radicals (Zhou et al. 2015). LA directly eliminates oxygen-free radicals, which reduce GSH consumption and increase the generation of GSH. The in vivo synthesis of GSH is affected by the utilization efficiency of cysteine. Therefore, LA can be quickly absorbed by cells, reduced to di-homo- $\gamma$-linolenic acid (DHLA), and distributed to various tissues. Cystine is reduced to cysteine by DHLA. The absorption rate of cysteine in cells is 10 times faster than that of cystine, which accelerates the biosynthesis of GSH. SOD is the main scavenger of superoxide-free radicals in vivo. In vitro tests demonstrated that LA could not effectively remove superoxide anion (Hess et al. 2000). The data in this study revealed that LA could reverse the decrease in SOD activity in the liver. Furthermore, it was observed that LA eliminated oxygenfree radicals through different pathways (Patrick 2006). 
This study revealed that NF- $\kappa B$ began to be activated after reperfusion, and the expression levels of inflammatory factors (MIP-2 and iNOS) increased, which initiated the chain reaction of inflammation. LA could significantly reduce the activation of $N F-\kappa B$, thereby decreasing the expression of inflammatory factors (MIP-2) and reducing the microcirculation disorder. A previous study revealed that LA inhibited the activation of nuclear transcription factors $N F-\kappa B$ and AP-1 during the late stage of ischemia and reperfusion through the pathway of PI3-kappa/Akt kinase (Gehrau et al. 2015).

MIP-2 also increases the expression of integrin beta 2 in neutrophils and further improves the adhesion of microvascular endothelial cells and neutrophils. This study revealed that NF- $\mathrm{B}$ began to be activated after reperfusion, and simultaneously activated the expression of MIP-2, which was continuously increased and maintained at a high level during the observation periods. The expression of MIP-2 significantly decreased in the treatment group compared with that in the injury group, suggesting that LA might reduce the activation of the inflammatory chain reaction by decreasing the activation of NF-kB.

NO is a signal molecule between the cells, is the first messenger, produced by a variety of body cells, and delivered through blood, lymph, various body fluids of different ways, to the surface of the cell membrane and cause specific reflection within the cell. Without NO, no more cells can work together and play as a part. NO in the body has two sources: one is the non enzymatic, chemical degradation and transformation of inorganic nitrogen from surface or intake; another is an enzyme, nitric oxide synthase catalyzed by L-arginine and guanidine produced. In the liver, nNOS and eNOS are only expressed in specific cells. Furthermore, nNOS is only detected in nerve tissues, while eNOS is continuously expressed at a low level in endothelial cells of the liver vessel wall. However, the expression of iNOS in the liver is not continuous and only reveals a high level in most of the liver cells under some stimuli (Muller et al. 2003). NO is produced by iNOS and can lead to HIR injury. These data revealed that LA reduced the formation of excess NO generated by reperfusion through the decrease in iNOS mRNA expression, and reduced cell damage caused by NOS superoxide and peroxynitrite anion formed by NO (Turamanlar et al. 2015, Patrick 2006).

The present study revealed that LA played protective roles in multiple processes of ischemiareperfusion induced through rat liver injury during the two stages of ischemia-reperfusion. This study opens up a new approach for the clinical prevention and treatment of ischemia-reperfusion, and improves the success rate of liver operation and liver transplantation. The aim of this study was to explore a new drug to protect the liver from ischemia-reperfusion injury, to investigate the role of alpha-Lipoic acid in ischemia-reperfusion injury and ultimately apply it to liver surgery.

\section{Conflict of Interest}

There is no conflict of interest.

\section{Acknowledgements}

We are particularly grateful to all the people who have given us help on our article.

\section{Abbreviations}

ATP: adenosine triphosphate, DHLA: dihydrolipoic acid, GPT: glutamic pyruvic transaminase, GSH: glutathione, HIR: hepatic ischemia-reperfusion, LA: alpha-lipoic acid, RT-PCR: reverse transcription-Polymerase Chain Reaction, SOD: superoxide dismutase.

\section{References}

ABDEL-GABER SA, IBRAHIM MA, AMIN EF, IBRAHIM SA, MOHAMMED RK, ABDELRAHMAN AM: Effect of selective versus non-selective cyclooxygenase inhibitors on ischemia-reperfusion-induced hepatic injury in rats. Life Sci 134: 42-48, 2015.

ABDIN AA, SARHAN NI: Intervention of mitochondrial dysfunction-oxidative stress-dependent apoptosis as a possible neuroprotective mechanism of $\alpha$-lipoic acid against rotenone-induced parkinsonism and L-DOPA toxicity. Neurosci Res 71: 387-395, 2011.

DENG H, ZUO X, ZHANG J, LIU X, LIU L, XU Q, WU Z, JI A: $\alpha$-lipoic acid protects against cerebral ischemia/reperfusion-induced injury in rats. Mol Med Rep 11: 3659-3665, 2015. 
GEHRAU RC, MAS VR, DUMUR CI, SUH JL, SHARMA AK, CATHRO HP, MALUF DG: Donor hepatic steatosis induce exacerbated ischemia-reperfusion injury through activation of innate immune response molecular pathways. Transplantation 99: 2523-2533, 2015.

GHIBU S, RICHARD C, DELEMASURE S, VERGELY C, MOGOSAN C, MURESAN A: An endogenous dithiol with antioxidant properties: alpha-lipoic acid, potential uses in cardiovascular diseases. Ann Cardiol Angeiol (Paris) 57: 161-165, 2008.

HESS DC, HOWARD E, CHENG C, CARROLL J, HILL WD, HSU CY: Hypertonic mannitol loading of NF-kappaB transcription factor decoys in human brain microvascular endothelial cells blocks upregulation of ICAM-I. Stroke 31: 1179-1186, 2000.

KIM HJ, JOE Y, YU JK, CHEN Y, JEONG SO, MANI N, CHO GJ, PAE HO, RYTER SW, CHUNG HT: Carbon monoxide protects against hepatic ischemia/reperfusion injury by modulating the miR-34a/SIRT1 pathway. Biochim Biophys Acta 1852: 1550-1559, 2015.

MIGNINI F, NASUTI C, FEDELI D, MATTIOLI L, COSENZA M, ARTICO M, GABBIANELLI R: Protective effect of alpha-lipoic acid on cypermethrin-induced oxidative stress in Wistar rats. Int J Immunopathol Pharmacol 26: 871-881, 2013.

MULLER C, DUNSCHEDE F, KOCH E, VOLLMAR AM, KIEMER AK: $\alpha$-Lipoic acid preconditioning reduces ischemia-reperfusion injury of the rat liver via the PI3-kinase/Akt pathway. Am J Physiol Gastrointest Liver Physiol 285: G769-G778, 2003.

NUNES C, BARBOSA RM, ALMEIDA L, LARANJINHA J: Nitric oxide and DOPAC-induced cell death: from GSH depletion to mitochondrial energy crisis. Mol Cell Neurosci 48: 94-103, 2011.

OCUIN LM, ZENG S, CAVNAR MJ, SORENSON EC, BAMBOAT ZM, GREER JB, KIM TS, POPOW R, DEMATTEO RP: Nilotinib protects the murine liver from ischemia/reperfusion injury. J Hepatol 57: 766-773, 2012.

PATRICK L: Lead toxicity part II: the role of free radical damage and the use of antioxidants in the pathology and treatment of lead toxicity. Altern Med Rev 11: 114-127, 2006.

PERALTA C, JIMENEZ-CASTRO MB, GRACIA-SANCHO J: Hepatic ischemia and reperfusion injury: effects on the liver sinusoidal milieu. J Hepatol 59: 1094-1106, 2013.

TANAKA Y, KAIBORI M, MIKI H, NAKATAKE R, TOKUHARA K, NISHIZAWA M, OKUMURA T, KWON AH: Alpha-lipoic acid exerts a liver-protective effect in acute liver injury rats. J Surg Res 193: 675-683, 2015.

TAO X, WAN X, XU Y, XU L, QI Y, YIN L, HAN X, LIN Y, PENG J: Dioscin attenuates hepatic ischemiareperfusion injury in rats through inhibition of oxidative-nitrative stress, inflammation and apoptosis. Transplantation 98: 604-611, 2014.

TURAMANLAR O, ÖZEN OA, SONGUR A, YAGMURCA M, AKCER S, MOLLAOGLU H, AKTAS C: Protective effect of alpha lipoic acid on rat sciatic nerve ischemia reperfusion damage. Balkan Med J 32: 196-202, 2015.

XUE L, XIE K, HAN X, YANG Z, QIU J, ZHAO Z, BAO T: Detrimental functions of IL-17A in renal ischemiareperfusion injury in mice. J Surg Res 171: 266-274, 2011.

YAMADA M, KAIBORI M, TANAKA H, HABARA K, HIJIKAWA T, TANAKA Y, OISHI M, OKUMURA T, NISHIZAWA M, KWON AH: Alpha-lipoic acid prevents the induction of iNOS gene expression through destabilization of its mRNA in proinflammatory cytokine-stimulated hepatocytes. Dig Dis Sci 57: 943-951, 2012.

ZHANG XL, YAN ZW, SHENG WW, XIAO J, ZHANG ZX, YE ZB: Activation of hypoxia-inducible factor-1 ameliorates postischemic renal injury via inducible nitric oxide synthase. Mol Cell Biochem 358: 287-295, 2011.

ZHOU HF, AI JC, WAN HT, HE Y, ZHANG YY, ZHAO T, FU W, YANG JH: Effect of Shenxiong injection on inflammation injury of ischemia-reperfusion injury rats. (Article in Chinese) Zhongguo Zhong Yao Za Zhi 40: 2408-2412, 2015. 